\title{
A Practical Exploration on Ideological and Political Construction of Curriculum in Higher Vocational Colleges under the Background of Internet — Taking Chinese Tea Culture as an Example
}

\author{
Xiang Gao ${ }^{1}$ Shuchen Yang ${ }^{2}$ Shanshan $\mathrm{Li}^{3 *}$ \\ Jiangxi Tourism\&Commerce Vocational College, Nanchang,Jiangxi,330000,China
}

\begin{abstract}
With the development of information technology, the communication between people is becoming more and more convenient, and the educational resources and teaching methods in colleges and universities are becoming more and more diversified. However, the conflict between ideology and mainstream values brought by open network environment often puzzles college students and seriously affects the development of their cognitive and moral level. Tea culture, as an important cultural resource, plays an important supporting role in moral construction and world civilization construction. Through excavating the ideological and political elements of tea culture, this paper systematically analyzes the application value of tea culture in ideological and political construction. On this basis, this paper makes full use of the platform and technical advantages of the Internet, puts forward the practical path of ideological and political construction in higher vocational colleges, and points out the direction for the development of higher vocational colleges and the cultivation of talents.
\end{abstract}

\section{INTRODUCTION}

As an important part of Chinese traditional culture, farming civilization and agricultural economy, tea culture plays an important role as a bridge between East and West. At this stage, more than 3 billion people in the world begin to drink tea, and drinking tea in daily life has become an indispensable part. Chinese tea has experienced the development of "Wanli Tea Road "," Maritime Silk Road" and other historical periods, and has slowly moved to the world and is loved and respected by the people of the world. As the carrier of media, the Internet has also developed rapidly, which has greatly changed the way people perceive external information. In view of this, from the perspective of the Internet, this paper takes "Chinese Tea Culture" as an example to explore the practical path of ideological and political construction in higher vocational colleges.

\section{THE SCIENTIFIC CONNOTATION OF TEA CULTURE}

With the continuous improvement of national status and cultural strength, tea culture is spreading and paying more and more attention among countries. Tea culture has been inherited in China for thousands of years, its unique charm makes tea culture play an important role in foreign exchanges. China is the hometown of tea, the development of tea culture has been more than 4700 years, its artistic connotation includes tea art, tea learning, tea books, tea stories and tea morality. At present, there are more than 100 countries in the world people are drinking tea, tea culture can reflect China's traditional etiquette and civilization literacy incisively and vividly[1]. Overall, tea culture has the following characteristics:

TABLE I. CHARACTERISTICS OF TEA CULTURE

\begin{tabular}{|l|l|}
\hline The realm of life & $\begin{array}{l}\text { theory that man is an integral part of } \\
\text { nature }\end{array}$ \\
\hline Philosophy & Peace is the most precious \\
\hline Mindfulness & Be sincere \\
\hline Reform spirit & Keep Up With the Times \\
\hline
\end{tabular}

\section{A. The realm of life: the unity of nature and man}

Tea culture embodies the Confucian gentleman's style, advocates the gentleman's thought and quality of doing something and doing something wrong, and opposes the action of the villain's profit-seeking and non-discounting means. It emphasizes that human beings and nature should be harmonious and symbiotic, and human beings can pursue quiet and harmonious life to the greatest extent in this environment. During the Tang and Song dynasties, the tea culture was in the heyday of its development.

\footnotetext{
*Corresponding author's e-mail:739960103@qq.com
} 


\section{B. Philosophy of dealing with matters}

With the popularization of tea culture, tea ceremony has also been developed rapidly. The ancients like to use tea friends to find similar friends in tea. In the division of tea, tea and tea exchange academic, tea drinkers can speak freely, in the process of tea tasting to express their own unique views. Simple tea culture makes the same simple, sincere people together, some of them will express their feelings about life, some will share their joy, some will discuss the work of things and so on. In short, people take care of each other and are friendly to each other[2].

\section{Self-cultivation}

The essence of tea ceremony is to repair the heart, participants need to guard against impatience, calm input. Modern noisy society and busy life make people's pace of work and life accelerate. In the process of chasing the satisfaction of the material world, it is difficult for people to stop to sum up and reflect on themselves. However, tea culture gives people the opportunity and occasion to taste life and realize life. As the main force of social development, college students begin to become impatient under the influence of various non-mainstream ideas, money interests, contradictions and conflicts, and their emotions are also easily affected by the external environment. Tea culture has a good effect on helping college students to quit impetuous qi and spread good qi.

\section{Reform spirit: keeping pace with the times}

The times are progressing, as the soft power of a country's development, culture must also change. People's daily life to make friends, often used to talk about the world in coffee, milk tea, Sprite, but the world also in our tea culture to deepen mutual understanding and understanding. In response to the needs of the market and external environment, the development of tea culture gradually presents the characteristics of branding, popularization and refinement. On the one hand, tea culture should adapt to the law of survival in the market economy environment and constantly innovate the connotation of culture. On the other hand, tea culture has innovated and developed its own cultural characteristics, value and taste on the basis of inheriting fine etiquette and traditional culture[3].

\section{ANALYSIS OF IDEOLOGICAL AND POLITICAL ELEMENTS IN CHINESE TEA CULTURE}

Chinese Tea Culture is an elective course for tea majors in colleges and universities. Students can master solid knowledge of tea culture and trace back the history of tea culture changes. In this process, students not only broaden their knowledge horizons, but also form the appreciation ability of culture and art. The teaching objectives of Chinese Tea Culture include the following aspects:
TABLE II. TEACHING OBJECTIVES OF CHINESE TEA CULTURE

\begin{tabular}{|l|l|}
\hline knowledge objective & $\begin{array}{l}\text { Content, Basic Theory and Research } \\
\text { Method of Tea Culture }\end{array}$ \\
\hline Capacity objectives & $\begin{array}{l}\text { Excavate and evaluate the values } \\
\text { and significance of tea culture }\end{array}$ \\
\hline \multirow{3}{*}{ Emotional goals } & $\begin{array}{l}\text { Form sound personality and moral } \\
\text { development; } \\
\text { Enrich cultural literacy, form } \\
\text { cultural identity and innovation } \\
\text { consciousness }\end{array}$ \\
\hline
\end{tabular}

Although the curriculum goal of Chinese Tea Culture is very mature, the goal of ideological and political education is not clear. At the 2016 ideological and political conference in colleges and universities, General Secretary Xi proposed that the ideological and political work should make good use of the classroom channel, teachers should actively improve the affinity and pertinence of ideological and political courses, and guide students to actively participate in the ideological and political classroom. In the process of tea tasting, the Chinese nation has formed a tea culture with national personality and innovative spirit, which embodies the Chinese nation's aesthetic taste, folk customs, self-improvement, selfless dedication and other cultural content. Although different schools interpret tea culture differently, they generally embody "and culture ". Therefore, the ideological and political teaching of Chinese Tea Culture in colleges and universities can be carried out around harmony culture[4].

China's "harmony culture" has been passed on for a long time, contains the unity of nature and man, harmony but difference, harmony and other ideas. The Chinese people have always adhered to the moral concept of peace, kindness and harmony and used it to restrain and regulate their behavior. And culture runs through the whole development stage of Chinese civilization, develops and perfects continuously in the process of inheritance, and finally becomes the core thought of Chinese traditional culture.

Through the study of relevant literature, it is found that the connotation of tea culture should include the key words such as "and, Lian, Qing, Zhong, Mei, Li" and so on. In 2013, the China International Tea Culture Research Institute put forward the core idea of "Qing Dynasty, beauty, harmony and respect ", in which" harmony "is the core of tea culture. It can be seen that tea culture is not only a culture, but also a spirit, which plays an important role in the cultivation of human mind from the aspects of body, nature and heart. The course teaching of "Chinese Tea Culture" in colleges and universities should actively excavate its potential ideological and political elements, enlighten students' dedication spirit with the tea nature of "low-key humility ", and guide students to learn meditation and introspection with the tea ceremony of" the unity of nature and man ". 


\section{CURRENT SITUATION OF IDEOLOGICAL AND POLITICAL CONSTRUCTION IN HIGHER VOCATIONAL COLLEGES}

\section{A. Insufficient overall focus}

Because the thought of college students is more complex, the Internet era is more diversified characteristics, so the ideological and political education of college students must unite the strength of all aspects. Only when schools, families and all sectors of society actively participate in the ideological and political work of college students can achieve the desired goal. However, in reality, ideological and political work presents an awkward situation of fighting alone. Students' families and various social organizations fail to carry out ideological and political work, and students can only accept more systematic and professional study in the ideological and political classroom. Because of the imperfection of the main body of education, the students lack systematic and in-depth study at the level of family education and social consciousness, and the students' classroom learning and after-class learning are separated, so ideological and political education only stays on the surface of campus education[5].

\section{B. Inadequate teaching staff}

The main body of ideological and political education in colleges and universities is usually limited to professional teachers and students working in ideological and political education, while most teachers do not realize their own ideological and political responsibilities and obligations. The educational thought of curriculum ideological and political education should cross the boundary of discipline, break the distinction between full-time and part-time ideological and political teachers, so as to realize the ideological and political construction of the whole curriculum system and the contingent of teachers.

However, due to the large mobility of teachers and limited development prospects, teachers are prone to produce other ideas in teaching activities, and can not concentrate on the research and reform of ideological and political work, which to a large extent also reduces the effectiveness of ideological and political work.

\section{Ideological and political concepts are lagging behind}

The ideological and political construction of higher vocational colleges should be planned from the angle of running schools and cultivating talents. However, due to the characteristics of higher vocational students and the demand of talent market, higher vocational colleges tend to cultivate students' professional skills in teaching, but ignore the development and formation of ideas. At the same time, neither the individual nor the whole teacher can recognize the ideological and political needs of classroom teaching, so it is the guidance of ideological and political aspects in teaching design and classroom interaction.

\section{CONSTRUCTION OF IDEOLOGICAL AND POLITICAL CURRICULUM IN HIGHER VOCATIONAL COLLEGES TAKING CHINESE TEA CULTURE AS AN EXAMPLE}

\section{A. To clarify the ideological and political value of tea culture}

As a kind of cultural education, ideological and political education is essentially the inheritance of culture. Tea culture and ideological and political education, whether cultural education function or self-cultivation, have obvious agreement. Therefore, ideological and political education in colleges and universities should actively introduce the role of tea culture in moral edification and value guidance. First of all, higher vocational teachers should clearly understand the connotation of tea culture, make students become the main body of tea culture dissemination and inheritance, and let students feel the true meaning and charm of tea culture in the process of students. Secondly, as the main place of cultural communication, colleges and universities should clearly understand the non-utilitarian value of tea culture in ideological and political education, promote the effective link between the curriculum of "Chinese Tea Culture" and ideological and political education, and give full play to the value of tea culture in ideological guidance.

\section{B. Perfect the curriculum structure and embody the essence of tea culture}

The integration of tea culture into ideological and political education in higher vocational colleges will greatly enrich the resources of ideological and political education and improve the educational system of ideological and political courses. It is worth noting that the integration of tea culture and ideological and political education is not accomplished overnight, but a gradual process. Teachers should encourage students to improve their self-cultivation and moral quality in the process of contact, understanding, understanding and understanding of tea culture. In addition, in order to maximize the educational function of tea culture, teachers should plan and integrate the content of tea culture step by step in ideological and political education activities. On the one hand, it can enrich the structure of curriculum, make students understand tea culture correctly and fall in love with tea culture.

\section{Actively carry out ideological and political practice activities of tea culture}

Although higher vocational colleges mainly train applied talents, there can be no separation between theory and 
technology. In addition to classroom teaching, teachers should actively broaden the channels of ideological and political education, change the way of ideological and political education, and introduce students' interest into the study of ideological and political content, so as to achieve twice the result with half the effort. Therefore, teachers can organize students to carry out tea art display, tea studio, tea party and other colorful practical activities. Teachers should not only let students experience the fun of tea art in activities, but also guide students to think about the meaning behind tea culture.

\section{Using Internet technology to optimize the ideological and political effect of tea culture}

More and more vocational colleges and universities begin to improve the overall level of teaching through Internet technology. In the ideological and political classroom, some teachers will combine the online teaching platform and network resources to optimize the course teaching through video, pictures, cases, shared courses and so on, and the course of "Chinese Tea Culture" is no exception. Teachers can search the origin, historical development, cultural connotation and educational function of tea culture through the network platform, break the limitation of time and space, close the distance between students and tea culture, and let students feel the influence and value of tea culture more deeply and directly.

\section{CONCLUSION}

There is still a gap between the ideal teaching of ideological and political education in higher vocational colleges. Although the course of ideological and political education is not a course of "Chinese Tea Culture ", the core idea of tea culture and the idea of ideological and political education do coincide. Taking tea culture as an opportunity to explore ideological and political work is undoubtedly to broaden the channels of ideological and political education in higher vocational colleges, to further enrich the content of ideological and political education, and to enable students to realize a free transformation between tea culture and ideological and political education. Finally, it will be beneficial to the overall development of students.

\section{REFERENCES}

1. Yang,D.Xia,A.P.(2020)A Study on the Coupling of College Counselors and Teachers of Ideological and Political Science in the Perspective of Tea Culture[J].Fujian tea.

2. Ma,K.(20200A Study on the Integration Path of Chinese Culture and Ideological and Political Education in Colleges and Universities - Taking Tea Culture as an Example[J].Fujian tea.

3. Liu,D.F.(2020)The Application of Chinese Tea Culture in the Ideological and Political in Higher Vocational Education[J].Fujian tea.
4. Jin,S.H.(2019)The Application of Tea Culture Thinking in Ideological and Political Classroom Management in Colleges and Universities[J].Journal of Anshun University.

5. Zhang,Z.H.(2019)Discussion on the Relationship between Ideological and Political Education Discourse and Tea Culture in Higher Vocational Colleges Based on the Perspective of WeChat Platform[J].Fujian tea. 